\title{
Quality characteristics of non steamed oriental melon Makgeolli by adding sucralose
}

\author{
Ok Mi Kim ${ }^{1}$, Yong Jun $\mathrm{Jo}^{2}$, Yong Jin Jeong ${ }^{3 *}$ \\ ${ }^{1}$ Food Art School, Taekyeung College, Gyeongsan 712-850, Korea \\ ${ }^{2}$ School of Food Science and Biotechnology, Kyungpook National University, Daegu 702-701, Korea \\ ${ }^{3}$ Department of Food Science and Technology, Keimyung University, Daegu 704-701, Korea
}

\section{Sucralose 첨가에 따른 참외 생쌀발효 막걸리의 품질특성}

\author{
김옥미 ${ }^{1} \cdot$ 조용준 $^{2} \cdot$ 정 용진 $^{3 *}$ \\ ${ }^{1}$ 대경대학교 호텔조리학부, ${ }^{2}$ 경북대학교 식품공학부, ${ }^{3}$ 계명대학교 식품가공학과
}

\begin{abstract}
This study examined the physicochemical quality characteristics of the oriental melon Makgeolli variant by addition of sucralose during its non-steamed fermentation process. The results showed a partial increase in initial sugar content in Makgeolli depending on the level of sucralose addition; and this slight increase in sugar content was exhibited in all intervals into which the sucralose was added during fermentation. The $\mathrm{pH}$ of Makgeolli did not exhibit significant changes according to the level of added sucralose until the fourth day of the fermentation process; and the total acidity of Makgeolli did not significantly change in accordance with the varied levels of added sucralose. Reducing sugar rapidly decreased in all intervals of the experiment during the first day of fermentation, and it was then increased slightly staring from the second day of the fermentation. Alcohol content in all experimental intervals was proportionally increased in accordance with the amount of added sucralose during the alcoholic fermentation process. The alcohol content was reached to the final alcohol contents of control (A) $11.27 \%, 0.001 \%$ (w/w) (B) $11.43 \%, 0.002 \%$ (w/w) (C) $11.80 \%$, and $0.003 \%$ (w/w) (D) 12.23\%. The levels of acetaldehyde, 1-propanol, isobutanol, and isoamyl alcohol in Makgeolli were all proportional to the level of the amount of sucralose added in the fermentation process. The organoleptic characteristics of Makgeolli was accorded with the level of the amount of sucralose. In the sensory evaluation, the experimental interval of $0.003 \%$ (w/w) (D) showed the highest scores of 3.30, $2.67,3.17$, and 3.20 in color, odor, taste and overall, respectively.
\end{abstract}

Key words : Makgeolli, non-steamed fermentation, sucralose, Oriental melon

\section{서 론}

참외는 박과에 속하는 한해살이 덩굴식물로서 여름철 대표적인 과채류 중 하나로 다른 과채류에 비해 열량과 비타민이 많으며 당도가 높고 칼륨, 칼슘 및 인 등의 무기질

*Corresponding author. E-mail : yjjeong@kmu.ac.kr Phone : 82-53-580-5557, Fax : 82-53-580-6477

Received 2 June 2015; Revised 17 June 2015; Accepted 18 June 2015.

Copyright (c) The Korean Society of Food Preservation. All rights reserved.
과 비타민 $\mathrm{A}$ 및 $\mathrm{C}$ 등이 풍부하여 식품으로 선호도가 높다 $(1,2)$. 참외에 함유되어 있는 포도당과 과당은 인체에 흡수 가 빨라 피로회복에 도움을 주고 꼭지 부분에 쓴맛을 내는 물질은 cucurbitacin으로 항암성분이며 예로부터 한방에서 참외 꼭지를 말려 진해, 거담, 변비, 황당 등에 처방하였다고 하며 급성 위장염, 중풍 등에도 효험이 있는 것으로 알려져 있다 $(3,4)$. 그러나 참외의 경우 저온에서 생육을 저해를 받 는 고온성 작물로 저장이 어려우며 주로 6월 및 7월에 여름 철 집중 출하되어 초과공급에 의한 가격경쟁력 유지가 힘들 다. 현재 참외가공과 활용에 한 연구로는 참외주스의 제조 (5), 유산균을 이용한 참외 발효식품의 제조(6) 및 전처리 
방법에 따른 건조참외의 품질조건 설정에 관한 연구(7) 등 이 보고되고 있으나 참외 저급과의 효율적 활용방안 연구는 아직 미흡하다. 경북 성주지역을 중심으로 참외의 가격하 락 방지 및 참외의 수급 조절을 위하여 대량으로 발생되는 저급과의 참외의 다양한 활용방안 개발이 절실히 요구된다(6).

막걸리는 우리나라를 대표하는 전통 재래주로 멥쌀을 원료로 누룩을 이용하여 빚은 발효주이며(8) 제조공정은 원료를 증자하여 누룩과 같은 발효제를 사용하여 당화와 알코올 발효를 거치는 과정으로 생산되며 쌀에 포함된 많은 영양분의 파괴 및 가열취 등의 단점이 있다(9). 최근 증자를 거치지 않은 전분질 원료를 이용한 당화 및 알코올 생산기 술이 개발되어 원가절감, 영양분 손실 방지 및 가열취 등이 보완된 비열처리 생쌀발효 막걸리가 대중적 기호도에 적합 하여 생산량이 증가하고 있다(10). 이러한 비열처리 막걸리 는 증자 막걸리에 비하여 당질, 비타민 B군 및 단백질 등이 풍부하고 다양한 아미노산 등이 풍부한 뿐만 아니라 영양성 도 우수한 것으로 알려져 있다(11). 또한 저도주이며 웰빙주 로서 젊은 여성층을 중심으로 인기를 얻기 시작하여 막걸리 의 소비가 다시 증대되고(12) 소비자들의 건강 지향적 문화 가 발달하면서 다양한 기능성과 독특한 풍미를 가진 막걸리 의 판매 및 인기가 꾸준히 높아지면서 차별화된 다양한 한약재, 과실 및 농축액을 첨가한 막걸리의 개발 및 제품화 가 활발히 이루어지고 있다.

Sucralose는 대체 감미료 중 하나로서 sucrose의 $\mathrm{OH}$ 기를 $\mathrm{Cl}$ 기로 치환시켜 제조한 인공 감미료이며 단맛 자체에는 변화가 없으나 단맛의 강도와 안정성이 인증된 무칼로리 감미료이며 설탕의 약 400 에서 800 배의 상대당도를 갖는다 고 알려져 있다(13). Sucralose의 경우 단맛 발현 시간과 감미특성이 설탕과 거의 유사하여 다른 감미료에 비하여 섭취에 이질감 등의 문제가 적다. 그리고 설탕보다 단맛이 약간 더 오래 지속되는 경향이 있으며 기타 감미료의 가장 큰 단점인 후미의 쓴맛이 적다(14). 또한 sucralose를 다른 감미료와 혼용할 경우 단맛의 상승작용이 있으며 기타 대체 감미료와 달리 결정성이 높고 산이나 열에도 매우 안정적이 다(15-17). 그러면서 저온살균, 초고온살균 및 베이킹과 같 은 고온의 가공을 필요로 하는 식품에서도 감미가 그대로 유지되고 낮은 $\mathrm{pH}$ 의 식품에서도 높은 안정성을 나타낸다 고 알려져 있다 $(18,19)$. 일반적으로 막걸리에 사용되는 감 미료로는 aspartame 및 acesulfame-K이 대부분 이용되나 쓴맛과 금속성의 후미가 있으며 $\mathrm{pH}$ 나 열에 대한 불안정한
단점이 있다(20,21). 이러한 단점 등을 보완하기 위하여 sucralose와 같은 대체감미료에 관한 막걸리 적용연구가 요 구 된다.

이에 본 연구에서는 선행 참외막걸리의 기호도 개선으로 sucralose의 첨가량에 따른 생쌀발효 참외막걸리에 미치는 이화학적 품질특성을 비교 검토하여 sucralose를 첨가한 막 걸리 개발 및 제품화에 관한 기초자료로 활용하고자 한다.

\section{재료 및 방법}

\section{재 료}

본 실험의 막걸리 제조에 사용한 백미는 2013년 생산된 햅쌀을 사용하였다. 시판효모인 Fermivin(Saccharomyces cerevisiae, DSM Food Specialties, Seclin, France)을 발효에 사용하였으며, 누룩은 시중 마트에서 구입하여 알코올발효 에 이용하였다. 참외 농축액의 경우 성주에서 참외 저급과 를 농축한 $50^{\circ} \mathrm{Brix}$ 농축액을 사용하였다. Glucoamylase (4,000 sp/g Heegu Co., Ltd., Simizyme, China) 및 sucralose는 (주KMF에서 제공받았다(22).

\section{Sucralose를 첨가한 참외 막걸리 제조}

참외 무증자 쌀막걸리의 원료 배합비는 Table 1 과 같은 비율로 혼합하여 알코올발효를 진행하였다. 밑술 담금은 분쇄한 쌀에 효모 $0.02 \%(\mathrm{w} / \mathrm{w})$, glucoamylase $5 \%(\mathrm{w} / \mathrm{w})$ 및 물 $300 \%(\mathrm{v} / \mathrm{w})$ 혼합하여 항온 배양기(HB-102L, Hanbaek Scientific Co., Bucheon, Korea)에서 $28^{\circ} \mathrm{C}$ 에서 30 시간 동안 배양하여 밑술 담금을 하였다. 본 담금은 쌀에 glucoamylase $5 \%(\mathrm{w} / \mathrm{w})$, 누룩 $6.5 \%(\mathrm{w} / \mathrm{w})$, 참외농축액 $6 \%(\mathrm{v} / \mathrm{w})$, 물 $300 \%(\mathrm{v} / \mathrm{w})$ 및 밑술 $10 \%(\mathrm{v} / \mathrm{v})$ 을 혼합하고 sucralose를 각각 무첨가(A), sucralose $0.001 \%(\mathrm{w} / \mathrm{w})$ 첨가군(B), sucralose $0.002 \%(\mathrm{w} / \mathrm{w})$ 첨가군 $(\mathrm{C})$ 및 sucralose $0.003 \%(\mathrm{w} / \mathrm{w})$ 첨가군 (D)을 각각 제조하여 항온 배양기에서 알코올 발효 4일 동안 품질특성을 조사하였다.

\section{$\mathrm{pH}$, 총산도 및 당도}

pH는 pH meter(Metrohm 691, Metrohm, Herisau, Switzerland)로 측정하였으며, 총산도는 시료 $1 \mathrm{~mL}$ 에 지시 약을 2 3방울 떨어뜨린 다음 $0.1 \mathrm{~N} \mathrm{NaOH}$ 를 중화 적정하 여 citric acid를 $(\%, \mathrm{w} / \mathrm{v})$ 로 환산하였다. 당도는 digital

Table 1. Ratio of materials in non steamed Oriental melon Makgeolli

\begin{tabular}{ccccccc}
\hline & \multicolumn{7}{c}{ Recipe } \\
\cline { 2 - 7 } & $\begin{array}{c}\text { Rice } \\
(\mathrm{g})\end{array}$ & $\begin{array}{c}\text { Yeast } \\
(\mathrm{g})\end{array}$ & $\begin{array}{c}\text { Purified enzyme } \\
(\mathrm{g})\end{array}$ & $\begin{array}{c}\text { Water } \\
(\mathrm{mL})\end{array}$ & $\begin{array}{c}\text { Nuruk } \\
(\mathrm{g})\end{array}$ & $\begin{array}{c}\text { Oriental melon concentrate } \\
(\mathrm{mL})\end{array}$ \\
\hline First step & 50 & 0.001 & 2.5 & 300 & & 28.8 \\
\hline Second step & 480 & & 24 & 1,440 & 31.2 & 28.2 \\
\hline
\end{tabular}


refractometer (PR-101, ATAGO Co., Tokyo, Japan)을 사용하 여 측정하였다.

\section{색도, 탁도 및 갈색도}

색도는 UV-visible spectrophotometer(UV-1601, Shimazu Co., Kyoto, Japan)로 $780 \mathrm{~nm}$ 에서 명도(L), 적색도(a) 및 황색 도(b)값을 측정한 후 Hunter's color value로 나타내었다. 이때 대조구는 증류수를 사용하였으며, 갈색도 및 탁도는 각각 $420 \mathrm{~nm}$ 및 $660 \mathrm{~nm}$ 에서 측정하였다.

\section{환원당 및 알코올함량}

환원당은 dinitrosalicylic acid(DNS)법(23)에 의해 측정하 였다. 시료 $1 \mathrm{~mL}$ 를 $100 \mathrm{~mL}$ volumetric flask에 넣고 증류수로 정용하였다. 정용한 용액 중 $1 \mathrm{~mL}$ 을 test tube에 넣고 $\mathrm{DNS}$ reagent $1 \mathrm{~mL}$ 과 혼합한 후 끓는 물에서 10 분간 가열하였다. 이후 상온에서 충분히 냉각하여 증류수 $3 \mathrm{~mL}$ 를 넣어 희석 하였다. 희석된 시료 $1 \mathrm{~mL}$ 을 취하여 UV-Visible spectrophotometer(UV-1601, Shimazu Co., Kyoto, Japan)를 이용하여 $546 \mathrm{~nm}$ 에서 흡광도를 측정하였다. 이때 glucose 를 표준물질로 사용하여 상기방법으로 작성한 표준곡선으 로부터 환산하였다. 알코올함량은 시료 $100 \mathrm{~mL}$ 을 증류한 다음 시료 $100 \mathrm{~mL}$ 증류 후 주정계를 이용하여 측정한 후 Gay-Luccac Table을 이용하여 $15^{\circ} \mathrm{C}$ 로 보정하였다.

\section{알코올성분}

알코올성분 분석은 참외 무증자 쌀막걸리 발효액을 0.45 $\mu \mathrm{m}$ membrane filter로 여과하여 국세청 주류분석규정에 따 라 Hewlett packard gas chromatography(5890, Hewlett packard Co., Palo Alto, CA, USA)를 이용하여 분석하였다 (24). 이때 사용한 column(19091N-233 HP-INNOWAX, 30 $\mathrm{m} \times 0.25 \mathrm{~mm} \times 0.5$, Agilent Technologies Co., Ltd., Santa Clara, California, USA)을 이용하였으며 carrier gas는 $\mathrm{N}_{2}$ (flow rate $1 \mathrm{~mL} / \mathrm{min}$ )를 사용하였다. $\mathrm{GC}$ oven 온도 program은 $40^{\circ} \mathrm{C}$ 에 서 2 분간 유지 후 분당 $2^{\circ} \mathrm{C}$ 승온하여 $130^{\circ} \mathrm{C}$ 에서 1 분간 유지 하였으며 detector는 FID, injector temperature은 $250^{\circ} \mathrm{C}$, detector temperature $260^{\circ} \mathrm{C}$ 로 설정하였다.

\section{관능검사}

Sucralose첨가에 따른 참외 무증자 쌀막걸리의 알코올함 량을 $6 \%$ 로 제성하여 24시간 냉장 보관하여 관능적 특성을 평가 하였으며 관능검사는 식품가공학을 전공하는 대학생 10 명을 관능검사 요원으로 선정하여 참외 무증자 쌀막걸리 의 관능적 요소를 잘 인지하도록 반복 훈련시킨 후 검사방 법과 평가 특성을 설명하였다. 기호도의 평가 항목은 맛 (taste), 향(flavor), 색(color) 및 종합적 기호도(overall acceptability)로서 5점 채점법을 이용하여 매우 좋다 : 5점, 보통이다 : 3점, 매우 나쁘다 : 1점으로 나타내었다.

\section{통계처리}

본 실험의 결과는 3회 반복으로 수행된 평균과 표준편차 로 나타내었으며 각 실험결과에 대한 통계분석은 SPSS 통 계 프로그램(Statistics Package for the Social Science, 18.0, SPSS Inc., Chicago, IL, USA)을 이용하여 one-way ANOVA (analysis of variation)로 분석한 뒤 Duncan's multiple range test로 실험군 평균치 간의 유의적 차이를 검증하였다.

\section{결과 및 고찰}

\section{당도, $\mathrm{pH}$ 및 총산도 변화}

Scralose첨가량에 따른 참외 무증자 쌀막걸리의 당도, $\mathrm{pH}$ 및 총산도는 Fig. 1 및 Fig. 2와 같다. 알코올발효 전 모든 구간에서 유의적인 차이는 나타나지 않았으나 sucralose첨 가의 경우 sucralose 무첨가(A) 비하여 조금씩 상승하는 경 향을 나타내었다. 알코올발효 1일째의 경우 sucralose 무첨 가(A)에서 $0.003 \%(\mathrm{w} / \mathrm{w})$ 첨가군(D)까지 sucralose첨가량에 따른 차이가 크지 않으나 발효가 진행됨에 따라 sucralose첨 가량에 따라 함량에 높은 구간에서 당도가 높아지는 경향을 나타났다. 알코올발효 4 일째 (A) $7.83^{\circ} \mathrm{Brix}$ 로 가장 낮게 나타났으며 $0.001 \%(\mathrm{w} / \mathrm{w})$ 첨가군(B) $8.53^{\circ} \mathrm{Brix}, 0.002 \%$ $(\mathrm{w} / \mathrm{w})$ 첨가군 $(\mathrm{C}) \quad 8.70^{\circ} \mathrm{Brix}$ 및 $0.003 \%(\mathrm{w} / \mathrm{w})$ 첨가군(D) $8.90^{\circ} \mathrm{Brix}$ 로 sucralose첨가량에 비례하여 당도가 증가하여 유의적인 차이를 보였다 $(\mathrm{p}<0.05)$. Park 등 $(25)$ 은 생쌀 막걸 리의 제조과정 중 당도의 경우 발효가 진행될수록 상승한다 고 보고하여 본 결과와 유사하였다. $\mathrm{pH}$ 는 알코올발효 전 무첨가(A) 4.82 에서 $0.003 \%(\mathrm{w} / \mathrm{w})$ 첨가군(D) 4.92 수준으로 유의적인 차이를 보였으나 $(\mathrm{p}<0.05)$, 값의 차이에서는 비슷 하게 나타났다. 이후 알코올발효 중 $\mathrm{pH}$ 는 1일째 3.82 3.97 로 급격하게 감소한 뒤 4일까지 3.82 3.96으로 큰 변화는 없었다. 본 연구의 참외 막걸리의 경우 sucralose의 첨가량 에 따른 차이는 없었으나 발효 기간 동안 $\mathrm{pH}$ 가 산성과 미산 성 사이이므로 알코올생성 능력이 좋은 것이라 판단된다. Sucralose첨가량에 따른 총산도의 변화로는 무첨가(A)에서 $0.003 \%(\mathrm{w} / \mathrm{w})$ 첨가군(D)까지 약 $0.17 \%$ 로 측정 되었으며 알 코올발효 기간에 따라 1일 $0.50 \sim 0.51 \%$ 로 무첨가(A)에서 $0.003 \%(\mathrm{w} / \mathrm{w})$ 첨가군(D)까지 모두 유의적인 차이를 보이며 증가하였고 발효 4일까지 $0.62 ~ 0.63 \%$ 로 미미하나 조금씩 증가하는 경향으로 나타났다. 이는 So 등(26)의 연구 결과 와 같이 발효 1 일째까지는 총산의 함량이 급격히 증가하며 그 이후에는 변화가 미미한 양상을 보여 본 실험의 결과와 유사한 경향을 보였다. 일반적으로 막걸리의 경우 제품화 과정에서 알코올함량을 조절하기 위하여 제성과정을 거치 는데 제성과정 중 첨가되는 정제수에 의하여 총산도는 감소 하고 $\mathrm{pH}$ 는 증가할 것으로 여겨진다. 


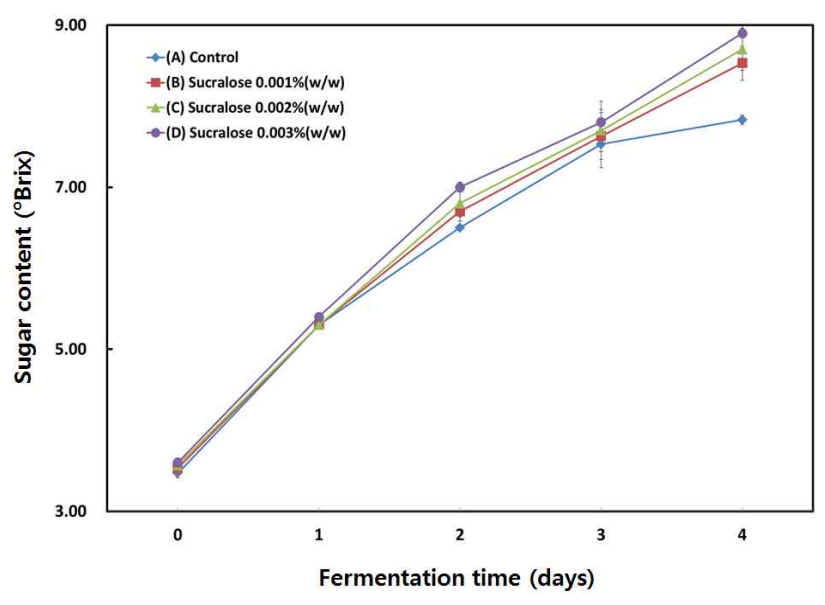

Fig. 1. Change in sugar content of non steamed Oriental melon Makgeolli after adding sucralose.

Values are mean $\pm \mathrm{SD}(\mathrm{n}=3)$.

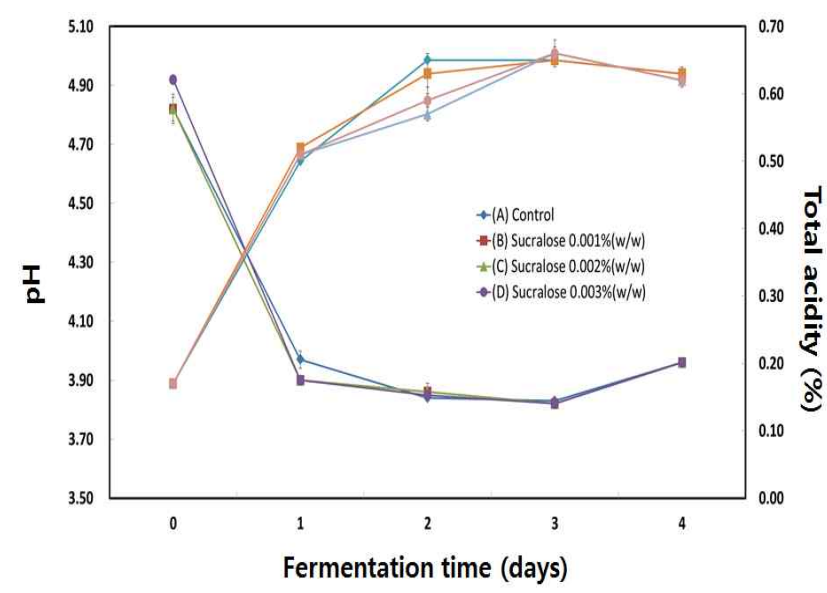

Fig. 2. Change in $\mathrm{pH}$ and total acidity of non steamed Oriental melon Makgeolli after adding sucralose.

Values are mean $\pm \mathrm{SD}(\mathrm{n}=3)$.

\section{색도, 탁도 및 갈색도 변화}

Sucralose첨가량에 따른 참외 무증자 쌀막걸리의 색도, 갈색도 및 탁도의 결과는 Table 2 및 Table 3 과 같다. Sucralose첨가량에 따른 $\mathrm{L}$ 값은 본 담금 직후 무첨가(A)에서 $0.003 \%(\mathrm{w} / \mathrm{w})$ 첨가군(D)까지 45.05 47.14로 나타났으나 sucralose첨가에 따른 유의적 차이는 나타나지 않았다 $(\mathrm{p}<0.05)$. 알코올발효가 진행됨에 따라 $\mathrm{L}$ 값이 점차 감소하 기 시작하여 발효 4일까지 33.12 37.03으로 sucralose함량 간의 유의적인 차이를 나타나지 않았다 $(\mathrm{p}<0.05)$. $\mathrm{a}$ 값은 본 담금을 진행한 직후 -0.02 -0.21로 나타났으며 모든 실험구 간의 알코올발효 중 1 일째 감소하였으나 발효가 진행됨에 따라 미미하게 증가하는 결과가 나타났다. $\mathrm{b}$ 값 또한 $\mathrm{a}$ 값과 유사하였으며 발효 1 일부터 감소하다 조금씩 증가하는 결 과를 보였다. 이는 Park 등(27)의 석류막걸리 제조과정 중 $\mathrm{a}$ 값 및 $\mathrm{b}$ 값의 경우 sucralose 무첨가(A)보다 1 일째 크게 감소 하였지만 알코올발효의 진행에 따라 조금씩 증가하였는
결과와 유사한 경향을 나타났다. 갈색도와 탁도의 경우 $\mathrm{a}$ 값 과 같이 1 일에 크게 감소하여 점차 증가하는 경향을 보였는 데 이는 발효 1 일째서 glucoamylase 및 누룩에 의해 가수 분해 되면서 그에 따른 분해 산물로 인해 증가한 것으로 생각된다.

\section{환원당 및 알코올함량 변화}

Scralose첨가량에 따른 참외 무증자 쌀막걸리의 알코올 발효 과정 중 환원당과 함량의 변화는 Fig. 3 과 같다. Sucralose의 첨가량에 따른 환원당은 발효 전 $0.003 \%(\mathrm{w} / \mathrm{w})$ 첨가군(D)에서 $1,915.85 \mathrm{mg} \%$ 로 가장 높았으며 $0.002 \%$ $(\mathrm{w} / \mathrm{w})$ 첨가군(C) $1,855.93 \mathrm{mg} \%, 0.001 \%(\mathrm{w} / \mathrm{w})$ 첨가군(B) $1,815.30 \mathrm{mg} \%$ 및 무첨가(A) $1,770.23 \mathrm{mg} \%$ 순으로 sucralose 첨가량에 따른 유의적인 차이를 보이며 나타났다( $<<0.05)$. 발효가 진행되면서 환원당의 함량은 모든 구간에서 감소하 는 경향을 보였으며 알코올발효 4 일째 $0.003 \%(\mathrm{w} / \mathrm{w})$ 첨가군 (D)경우 $252,23 \mathrm{mg} \%$ 로 감소하였으나 다른 sucralose첨가구 간에 비하여 잔존 환원당은 가장 높았다. Sucralose 무첨가 (A)의 경우 $177.58 \mathrm{mg} \%$ 로 가장 낮게 나타났으며 $0.001 \%$ $(\mathrm{w} / \mathrm{w})$ 첨가군(B) $210.66 \mathrm{mg} \%$ 및 $0.002 \%(\mathrm{w} / \mathrm{w})$ 첨가군(C) $226.15 \mathrm{mg} \%$ 수준으로 sucralose첨가량의 증가에 따라 환원 당의 함량도 유의적으로 높게 나타났다. 무증자 쌀막걸리 의 경우 알코올발효에서 환원당 생성이 느리게 일어나며 전분분해효소가 많다고 하더라도 쌀 자체의 단단한 구조로 인하여 당류가 매우 느리게 생성 된다(28). 하지만 본 연구 에서 알코올발효 전 생쌀을 분쇄하여 분말 형태로 한 다음 실험을 진행한 결과 알코올발효 전 환원당 함량이 높게 나온 것으로 판단된다. 이는 Park 등(29)의 무증자 쌀막걸리 제조에서 알코올발효에서 분쇄된 쌀을 이용할 경우 발효 12 시간 이후 환원당이 급격히 감소한다고 보고하여 본 실 험결과와 유사하였다. 이와 같은 발효 속도의 차이는 원료 의 입자크기에 따라 당화효소의 가수분해 작용의 용이성에 따른 것이라 판단된다. Sucralose의 첨가량에 따른 알코올 함량은 알코올발효 1 일째 무첨가(A) $3.87 \%, 0.001 \%(\mathrm{w} / \mathrm{w})$ 첨가군(B) $4.50 \%, \quad 0.002 \%(\mathrm{w} / \mathrm{w})$ 첨가군(C) $4.63 \%$ 및 $0.003 \%(\mathrm{w} / \mathrm{w})$ 첨가군(D) $4.87 \%$ 로 sucralose 첨가량이 많을수 록 높게 나타나면서 유의적인 차이를 나타냈었다( $<<0.05)$. 이후 알코올발효 4 일까지 유의적 차이를 보이며 증가하면 서 $0.003 \%(\mathrm{w} / \mathrm{w})$ 첨가군(D)에서 $12.23 \%$ 로 가장 높았고 $0.002 \%(\mathrm{w} / \mathrm{w})$ 첨가군 $(\mathrm{C}) 11.80 \%, 0.001 \%(\mathrm{w} / \mathrm{w})$ 첨가군(B) $11.42 \%$, 무첨가(A) $11.27 \%$ 의 순으로 높게 나타났다. 일반 적으로 합성감미료의 경우 발효에 이용되지 않으며 감미에 만 영향을 주는 것으로 알려져 있으나 본 연구결과 참외 막걸리 제조 중 sucralose첨가량에 따른 알코올함량은 sucralose첨가량이 높을수록 유의적으로 높게 나타났다. 이 에 반하여 sucralose첨가량에 따른 환원당 함량의 차이는 알코올발효 전 약 40 60 mg\%로 나타났으나 알코올발효 
Table 2. Hunter's color value and turbidity of non steamed Oriental melon Makgeolli after adding sucralose

\begin{tabular}{|c|c|c|c|c|c|c|}
\hline & & \multirow{2}{*}{$\begin{array}{l}\text { Times } \\
\text { (days) }\end{array}$} & \multicolumn{4}{|c|}{ Sucralose content $(\mathrm{w} / \mathrm{w})$} \\
\hline & & & (A) Control & (B) $0.001 \%$ & (C) $0.002 \%$ & (D) $0.003 \%$ \\
\hline \multirow{15}{*}{$\begin{array}{l}\text { Hunter's } \\
\text { color } \\
\text { value }\end{array}$} & \multirow{5}{*}{$\mathrm{L}$} & 0 & $47.14 \pm 6.57^{1 \mathrm{~ns} 2 \mathrm{a} 33)}$ & $45.05 \pm 4.71^{\mathrm{a}}$ & $46.13 \pm 5.62^{\text {ns }}$ & $45.30 \pm 7.10^{\mathrm{a}}$ \\
\hline & & 1 & $29.73 \pm 1.30^{\mathrm{B} 4 \mathrm{~b}}$ & $40.45 \pm 2.83^{\mathrm{Aab}}$ & $41.44 \pm 6.82^{\mathrm{A}}$ & $46.67 \pm 5.39^{\mathrm{Aa}}$ \\
\hline & & 2 & $34.62 \pm 0.82^{\mathrm{Cb}}$ & $37.02 \pm 1.39^{\mathrm{ABb}}$ & $36.10 \pm 3.49^{\mathrm{A}}$ & $35.31 \pm 3.51^{\mathrm{BCb}}$ \\
\hline & & 3 & $35.11 \pm 0.66^{\mathrm{nsb}}$ & $37.94 \pm 0.60^{b}$ & $38.55 \pm 0.83$ & $37.08 \pm 6.12^{\mathrm{ab}}$ \\
\hline & & 4 & $34.45 \pm 2.19^{\text {nsb }}$ & $37.03 \pm 2.50^{\mathrm{b}}$ & $34.62 \pm 3.89$ & $33.12 \pm 2.94^{\mathrm{b}}$ \\
\hline & \multirow{5}{*}{$\mathrm{a}$} & 0 & $-0.02 \pm 0.13^{\mathrm{nsa}}$ & $-0.02 \pm 0.13^{a}$ & $-0.13 \pm 0.13^{\mathrm{a}}$ & $-0.21 \pm 0.21^{a}$ \\
\hline & & 1 & $-0.41 \pm 0.04^{\mathrm{Ab}}$ & $-0.74 \pm 0.10^{\mathrm{Bb}}$ & $-0.76 \pm 0.24^{\mathrm{ABc}}$ & $-0.93 \pm 0.19^{\mathrm{Bb}}$ \\
\hline & & 2 & $-0.39 \pm 0.06^{\mathrm{Ab}}$ & $-0.24 \pm 0.05^{\mathrm{Aa}}$ & $-0.22 \pm 0.07^{\mathrm{BCba}}$ & $-0.36 \pm 0.09^{\mathrm{Aa}}$ \\
\hline & & 3 & $-0.35 \pm 0.04^{\mathrm{nsb}}$ & $-0.22 \pm 0.01^{\mathrm{a}}$ & $-0.24 \pm 0.02^{\mathrm{b}}$ & $-0.24 \pm 0.09^{\mathrm{a}}$ \\
\hline & & 4 & $-0.31 \pm 0.05^{\mathrm{nsb}}$ & $-0.25 \pm 0.04^{\mathrm{a}}$ & $-0.21 \pm 0.09^{\mathrm{a}}$ & $-0.27 \pm 0.08^{\mathrm{a}}$ \\
\hline & \multirow{5}{*}{$\mathrm{b}$} & 0 & $11.17 \pm 1.93^{\mathrm{nsa}}$ & $10.39 \pm 0.44^{\mathrm{a}}$ & $11.08 \pm 1.08^{\mathrm{ca}}$ & $11.02 \pm 1.23^{\mathrm{ca}}$ \\
\hline & & 1 & $4.96 \pm 0.42^{\mathrm{Bd}}$ & $5.96 \pm 0.64^{\mathrm{ABc}}$ & $6.34 \pm 0.74^{\mathrm{ABc}}$ & $7.00 \pm 0.72^{\mathrm{Ab}}$ \\
\hline & & 2 & $6.50 \pm 0.33^{\mathrm{Cbc}}$ & $5.52 \pm 1.83^{\mathrm{Cc}}$ & $7.20 \pm 0.54^{\mathrm{Bc}}$ & $5.60 \pm 2.14^{\mathrm{Ac}}$ \\
\hline & & 3 & $7.50 \pm 0.19^{\text {nsb }}$ & $7.89 \pm 0.06^{b}$ & $7.93 \pm 0.27^{b}$ & $7.66 \pm 0.93^{b}$ \\
\hline & & 4 & $10.77 \pm 0.57^{\text {nsa }}$ & $10.92 \pm 0.34^{\mathrm{a}}$ & $10.95 \pm 0.23^{\mathrm{a}}$ & $11.09 \pm 0.41^{\mathrm{a}}$ \\
\hline
\end{tabular}

${ }^{1)}$ Values are mean \pm SD $(\mathrm{n}=3)$.

${ }^{2)}$ Not significant.

${ }^{3) a-d}$ Means within a column not followed by the same letter are significantly different $(p<0.05)$

${ }^{4) A-D}$ Means within a row not followed by the same letter are significantly different $(p<0.05)$.

Table 3. Turbidity and brown color of non steamed Oriental melon Makgeolli after adding sucralose

\begin{tabular}{|c|c|c|c|c|c|}
\hline & \multirow{2}{*}{$\begin{array}{l}\text { Time } \\
\text { (days) }\end{array}$} & \multicolumn{4}{|c|}{ Sucralose content $(w / w)$} \\
\hline & & (A) Control & (B) $0.001 \%$ & (C) $0.002 \%$ & (D) $0.003 \%$ \\
\hline \multirow{5}{*}{ Turbidity } & 0 & $0.57 \pm 0.11^{1 \mathrm{~ns} 22}$ & $0.60 \pm 0.08^{\mathrm{b3})}$ & $0.62 \pm 0.12^{\mathrm{ns}}$ & $0.60 \pm 0.13^{b}$ \\
\hline & 1 & $0.99 \pm 0.00^{\mathrm{A} 4)}$ & $0.79 \pm 0.02^{\mathrm{ABa}}$ & $0.79 \pm 0.13^{\mathrm{AB}}$ & $0.76 \pm 0.19^{\mathrm{Bab}}$ \\
\hline & 2 & $0.71 \pm 0.10^{\mathrm{ns}}$ & $0.70 \pm 0.15^{\mathrm{ab}}$ & $0.70 \pm 0.12$ & $0.78 \pm 0.07^{\mathrm{ab}}$ \\
\hline & 3 & $0.77 \pm 0.06^{\mathrm{ns}}$ & $0.78 \pm 0.06^{\mathrm{a}}$ & $0.78 \pm 0.02$ & $0.83 \pm 0.00^{\mathrm{a}}$ \\
\hline & 4 & $0.79 \pm 0.06^{\mathrm{ns}}$ & $0.79 \pm 0.04^{\mathrm{a}}$ & $0.79 \pm 0.03$ & $0.78 \pm 0.07^{\mathrm{ab}}$ \\
\hline \multirow{5}{*}{ Brown color } & 0 & $0.96 \pm 0.11^{\mathrm{nsc}}$ & $0.99 \pm 0.12^{\mathrm{ns}}$ & $1.04 \pm 0.14^{\mathrm{ns}}$ & $1.01 \pm 0.16^{\mathrm{ns}}$ \\
\hline & 1 & $1.28 \pm 0.02^{\mathrm{nsa}}$ & $1.02 \pm 0.06$ & $1.01 \pm 0.22$ & $1.02 \pm 0.21$ \\
\hline & 2 & $1.00 \pm 0.13^{\mathrm{nsbc}}$ & $0.99 \pm 0.17$ & $0.99 \pm 0.11$ & $1.15 \pm 0.10$ \\
\hline & 3 & $1.16 \pm 0.06^{\mathrm{Aa}}$ & $1.09 \pm 0.06^{\mathrm{B}}$ & $1.11 \pm 0.02^{\mathrm{AB}}$ & $1.15 \pm 0.00^{\mathrm{AB}}$ \\
\hline & 4 & $1.14 \pm 0.05^{\mathrm{ABab}}$ & $1.08 \pm 0.09^{\mathrm{AB}}$ & $1.17 \pm 0.02^{\mathrm{A}}$ & $1.04 \pm 0.02^{\mathrm{B}}$ \\
\hline
\end{tabular}

\footnotetext{
${ }^{1)}$ Values are mean \pm SD $(n=3)$.

${ }^{2)}$ Not significant.

${ }^{3) a-d}$ Means within a column not followed by the same letter are significantly different $(p<0.05)$

${ }^{4) A-D}$ Means within a row not followed by the same letter are significantly different $(p<0.05)$.
}

후 약 16 33 mg\%로 차이가 감소하였다. 이러한 결과는 sucralose의 구조특징에서 $\mathrm{Cl}$ 기의 경우 상대적으로 약한 결 합으로 되어 있으며 산화 및 수분 등에 의하여 쉽게 분해되 는데 이러한 과정 중 $\mathrm{Cl}$ 기가 $\mathrm{OH}$ 로 치환되면서 sucrose 및 fructose 등의 발효성 당과 같은 물질로 전환되므로 본 연구 에서 sucralose의 경우 일부 알코올 발효 과정 중 발효성
당으로 전환되어 알코올발효에 이용된 것이라 여겨진다 (30).

\section{알코올성분 함량}

Sucralose첨가량에 따른 참외 막걸리의 알코올성분을 분 석한 결과 Table 4 와 같다. 주요 알코올성분으로 acetaldehyde, 


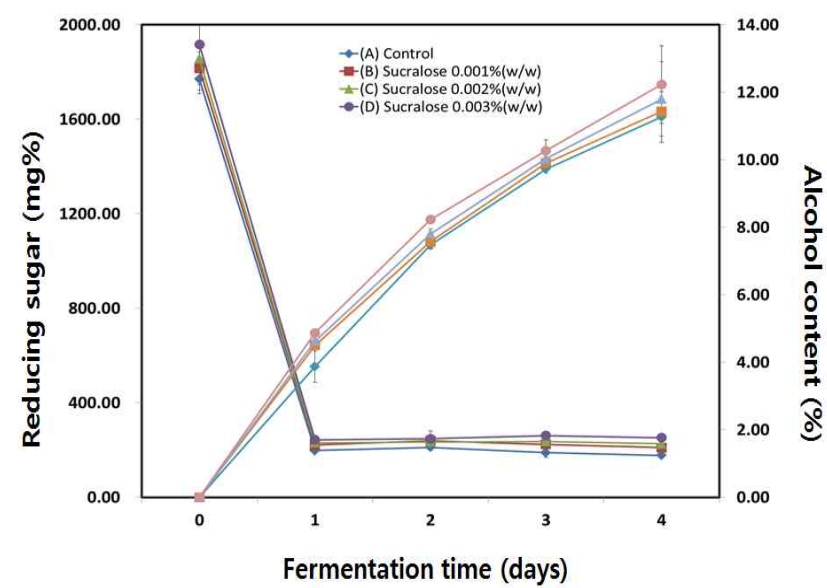

Fig. 3. Change in reduced sugar content and alcohol content of non steamed Oriental melon Makgeolli after adding sucralose. Values are mean $\pm \mathrm{SD}(\mathrm{n}=3)$.

methanol, ethanol, n-propanol, isobutanol 및 isoanmlyalcohol 등 6종이 검출되었다. Sucralose 첨가량에 따른 acetaldehyde 의 함량의 경우 $0.003 \%(\mathrm{w} / \mathrm{w})$ 첨가군(D)에서 $128.13 \mathrm{ppm}$ 으로 가장 높았으며 $0.002 \%(\mathrm{w} / \mathrm{w})$ 첨가군(C) $121.69 \mathrm{ppm}$, $0.001 \%(\mathrm{w} / \mathrm{w})$ 첨가군(B) $110.70 \mathrm{ppm}$ 및 무첨가(A) 96.64 $\mathrm{ppm}$ 순으로 유의적으로 함량차이를 보였다 $(\mathrm{p}<0.05)$. 막걸 리의 methanol 함량 기준은 $500 \mathrm{ppm}$ 이하로 규정 되어 있는 데 (A) (D) 모두 규격에 적합한 것으로 나타났다. 미량 알코 올성분 중 자극취를 나타내는 n-propanol 역시 유의적인 차이를 보였으며 sucralose $0.003 \%(\mathrm{w} / \mathrm{w})$ 첨가군(D)에서 $144.14 \mathrm{ppm}$ 로 가장 높았고 $0.002 \%(\mathrm{w} / \mathrm{w})$ 첨가군(C) 126.87 $\mathrm{ppm}, 0.001 \%(\mathrm{w} / \mathrm{w})$ 첨가군(B) $107.38 \mathrm{ppm}$ 및 무첨가(A) $86.29 \mathrm{ppm}$ 순으로 나타났다. 알코올성분 중 막걸리, 맥주
및 청주 등에서 중요한 풍미성분으로 평가 되는 isoamylalcohol 함량은 $0.003 \%(\mathrm{w} / \mathrm{w})$ 첨가군(D)에서 $162.48 \mathrm{ppm}$ 으로 가장 높았으며 $0.002 \%(\mathrm{w} / \mathrm{w})$ 첨가군(C) $158.48 \mathrm{ppm}, 0.001 \%$ $(\mathrm{w} / \mathrm{w})$ 첨가군(B) $107.38 \mathrm{ppm}$ 및 무첨가(A) $136.82 \mathrm{ppm}$ 의 순으로 유의적인 차이를 나타냈다( $\mathrm{p}<0.05) . \mathrm{n}$-propanol, isobutanol 및 isoamylcohol 등은 fusel oil의 종류로서 함량이 많을 경우 향미가 나빠지고 두통 및 숙취의 원인이 되어 인체에 유해하나 소량으로 존재할 경우 주류의 맛과 향을 향상시켜 풍미를 증진시키는 작용을 하는데 sucralose의 첨 가량이 증가할수록 참외 막걸리의 n-propanol, isobutanol 및 isoamylcohol 등의 함량이 증가하였으며 모든 구간에서 국 내 막걸리 fusel oil 함량 기준인 $1 \mathrm{mg} / \mathrm{mL}$ 이하로 나타났다.

\section{관능적 특성}

우리나라의 주세법 시행령의 막걸리 알코올함량은 6\% 8\%로(31) 본 참외 막걸리의 경우 발효 후 $6 \%$ 로 제성하 여 관능검사를 실시한 결과 Table 5 와 같다. 알코올의 함량 은 제성할 경우 추가적인 가수량 차이로 인하여 sucralose첨 가량에 따른 참외 막걸리의 관능적인 특성에서 차이가 있을 것이라 예상된다. 색의 경우 sucralose $0.003 \%(\mathrm{w} / \mathrm{w})$ 첨가군 (D)가 3.30으로 가장 높았으며 $0.001 \%(\mathrm{w} / \mathrm{w})$ 첨가군(B), $0.001 \%(\mathrm{w} / \mathrm{w})$ 첨가군 $(\mathrm{C})$ 는 3.00 , 무첨가 $(\mathrm{A}) 2.83$ 으로 나타 났다. 향의 경우 무첨가(A)가 3.00 으로 가장 높았고 나머지 구간은 2.33 2.83으로 나타났다. 맛은 sucralose $0.003 \%$ $(\mathrm{w} / \mathrm{w})$ 첨가군(D)에서 3.17 로 나타났으며 나머지 구간은 2.83 3.00으로 나타났다. 종합적 기호도는 sucralose $0.003 \%$ $(\mathrm{w} / \mathrm{w})$ 첨가군 $(\mathrm{D})$ 에서 가장 높았으며 $0.002 \%(\mathrm{w} / \mathrm{w})$ 첨가군 $(\mathrm{C}), 0.001 \%(\mathrm{w} / \mathrm{w})$ 첨가군(B) 및 무첨가(A) 순으로 나타났 다. 이는 색과 향의 비중보다 맛의 비중이 종합적 기호도의

Table 4. Alcohol components of non steamed Oriental melon Makgeolli after adding sucralose

\begin{tabular}{lcccc}
\hline & \multicolumn{4}{c}{ Sucralose content (w/w) } \\
\cline { 2 - 5 } & (A) Control & (B) $0.001 \%$ & $(\mathrm{C}) 0.002 \%$ & $(\mathrm{D}) 0.003 \%$ \\
\hline Acetaldehyde & $96.64 \pm 4.58^{2)(3)}$ & $110.70 \pm 2.97^{\mathrm{B}}$ & $121.69 \pm 2.47^{\mathrm{A}}$ & $128.13 \pm 4.51^{\mathrm{A}}$ \\
Methanol & $\mathrm{Tr}^{4}$ & $\mathrm{Tr}$ & $\mathrm{Tr}$ & $\mathrm{Tr}$ \\
2-Propanol & $\mathrm{ND}^{5)}$ & $\mathrm{ND}$ & $\mathrm{ND}$ & $\mathrm{ND}$ \\
Ethanol & $10.74 \pm 0.35^{\mathrm{C}}$ & $11.29 \pm 0.26^{\mathrm{BC}}$ & $11.66 \pm 0.41^{\mathrm{AB}}$ & $12.20 \pm 0.36^{\mathrm{A}}$ \\
\hline 1-Propanol & $86.29 \pm 5.94^{\mathrm{D}}$ & $107.38 \pm 5.89^{\mathrm{C}}$ & $126.87 \pm 11.70^{\mathrm{B}}$ & $144.14 \pm 7.89^{\mathrm{A}}$ \\
Isobutanol & $136.82 \pm 1.50^{\mathrm{B}}$ & $144.35 \pm 4.39^{\mathrm{B}}$ & $158.48 \pm 6.28^{\mathrm{A}}$ & $162.48 \pm 6.34^{\mathrm{A}}$ \\
1-butanol & $\mathrm{ND}$ & $\mathrm{ND}$ & $\mathrm{ND}$ & $\mathrm{ND}$ \\
Isoamylalcohol & $439.58 \pm 12.74^{\mathrm{ns}}$ & $463.38 \pm 16.12$ & $470.24 \pm 27.92$ \\
1-pentanol & $\mathrm{ND}$ & $448.37 \pm 7.00$ & $\mathrm{ND}$ & $\mathrm{ND}$ \\
\hline
\end{tabular}

\footnotetext{
${ }^{11)}$ Unit: \%.

${ }^{2)}$ Values are mean \pm SD $(\mathrm{n}=3)$.

3)A-D Means within a row not followed by the same letter are significantly different $(\mathrm{p}<0.05)$.

${ }^{4)}$ Trace.

${ }^{5}$ Not detected.

${ }^{6}$ Not significant.
} 
Table 5. Sensory properties of non steamed Oriental melon Makgeolli after adding sucralose

\begin{tabular}{cccccc}
\hline \multicolumn{5}{c}{ Sucralose content $(\mathrm{w} / \mathrm{w})$} \\
\hline \multirow{3}{*}{ Preference } & (A) Control & (B) $0.001 \%$ & (C) $0.002 \%$ & (D) $0.003 \%$ \\
& Color & $2.83 \pm 0.41^{1 \text { 1)s } 2)}$ & $3.00 \pm 0.63$ & $3.00 \pm 0.89$ & $3.30 \pm 0.82$ \\
& odor & $3.00 \pm 0.00^{\mathrm{ns}}$ & $2.33 \pm 0.52$ & $2.83 \pm 0.75$ & $2.67 \pm 0.82$ \\
& Taste & $3.00 \pm 0.63^{\mathrm{ns}}$ & $3.00 \pm 0.89$ & $2.83 \pm 0.75$ & $3.17 \pm 0.75$ \\
& Overall & $2.00 \pm 0.89^{\mathrm{B} 3}$ & $2.50 \pm 0.55^{\mathrm{B}}$ & $2.33 \pm 0.52^{\mathrm{B}}$ & $3.20 \pm 0.84^{\mathrm{A}}$ \\
\hline
\end{tabular}

${ }^{1)}$ Values are mean $\pm \mathrm{SD}(\mathrm{n}=3)$

${ }^{2)}$ Not significant.

${ }^{3) A-D}$ Means within a row not followed by the same letter are significantly different $(p<0.05)$.

영향을 끼치는 것으로 여겨진다. 관능검사 결과 알코올발 효 과정 중 sucralose첨가의 경우 발효 전 첨가에서 관능적 특성보다 알코올함량 및 기타 이화학적 특성에 영향을 주는 것으로 판단된다. 따라서 관능적 특성을 효과적으로 상승 시키려면 발효 후 sucralose첨가가 관능적 특성에 더욱 유리 할 것으로 판단된다.

\section{요 약}

본 연구에서는 비열처리 참외막걸리 제조과정 중 sucralose첨가량에 따른 이화학적 품질 특성을 조사하였다. 그 결과 초기 당도는 sucralose 함량이 높을수록 일부 증가 하였으며 발효가 진행됨에 따라 모든 첨가구간에서 조금씩 증가하는 경향을 보였다. $\mathrm{pH}$ 는 발효 4일까지 sucralose 함량 에 따른 큰 차이가 없었으며 총산도의 경우도 sucralose 함 량에 따라 큰 차이가 나타나지 않았다. 환원당의 경우 1 일째 에 모든 실험구간에서 급격히 감소한 뒤 2일부터 조금씩 증가하는 경향을 보였다. 알코올함량은 sucralose의 첨가량 에 따라 알코올발효가 진행되면서 알코올함량이 증가하여 발효 종료 후 무첨가(A) $11.27 \%, 0.001 \%(\mathrm{w} / \mathrm{w})$ 첨가군(B) $11.43 \% 0.002 \%(\mathrm{w} / \mathrm{w})$ 첨가군(C) $11.80 \%$ 및 $0.003 \%(\mathrm{w} / \mathrm{w})$ 첨가군(D) $12.23 \%$ 로 나타났다. 알코올성분 중 acetaldehyde, 1-propanol, isobutanol 및 isoamylalcohol 모두 sucralose첨가 량에 많을수록 높은 함량을 보였다. Suralose 첨가에 따른 관능적 특성은 sucralose $0.003 \%(\mathrm{w} / \mathrm{w})$ 첨가군(D)에서 color, odor, taste 및 overall이 각각 $3.30,2.673 .17$ 및 3.20으로 가장 높았다.

\section{References}

1. Kim TY, Lee SH, Kim JS, Kim SB (2006) Pre-treatment and storage condition of abnormal fermented oriental melon for fermentation use. Korean J Soc Appl Biol Chem, 49, 202-208
2. Jo YJ, Jang SY, Kim OM, Park CW, Jeong YJ (2010) Effects of sugars addition in alcohol fermentation of oriental melon. Korean J Soc Food Sci Nutr, 39, 1359-1365

3. Kim KC (2002) Changes of physiological by abnormal fermentation of 'Gumssaragi' melon fruit. MS Thesis, Chungnam National University, Korea

4. Shin YS, Teon IK, Do HW, Cheung JD, Kang CK, Choi SY, Youn SJ, Cho JG, Kwoen DJ (2008) Antioxidant and antimicrobial effects of extract with water and ethanol of oriental melon (Cucumis melo L. var makuwa Makino). Korean J Soc Appl Biol Chem, 51, 194-199

5. Cha SK, Chun HI, Hong SS, Kim WJ, Koo YJ (1993) Manufacture of fermented cantaloupe melon with lactic starter culture. Korean J Food Sci Technol, 25, 386-390

6. Shin DH, Koo YJ, Kim CO, Min BY, Suh KB (1978) Studies on the production of watermelon and cantaloupe melon juice. Korean J Food Sci Technol, 10, 215-223

7. Kim JG, Jeong ST, Jang HS, Kim YB (1997) Quality properties of dried melon with different pre-treatments. Korean J Post-harvest Sci Technol Agric Products, 4, 147-153

8. Son, HS, Park BD, Ko BK, Lee CH (2011) Quality characteristics of Takju produced by adding different amounts of water. Korean J Food Sci Technol, 43, 453-457

9. Kim MJ, Kim BH, Han JK, Lee SY, Kim KS (2011) Analysis of quality properties and fermentative microbial profiles of Takju and Yakju brewed with or without steaming process. J Food Hyg Safety, 26, 64-69

10. Ueda S, Zenin CT, Monteiro DA, Park YK (1982) Ethanol production from raw cassava starch. Biotechnol Bioeng, 23, 291-299

11. Bae SM, Lee YH, Kang SA, Cheong C (2008) Effect of traditional nuruk ratio and yeast on the fermentation and quality of Yakju. East J Asian Soc Dietary Life, 18, 
41-48

12. An SY (2011) Study about development of Makgeolli brand design for sales in duty-free stores. MS Thesis, Hanyang University, Korea

13. Nelson AL (2000) Sweeteners : alternative. Properties of high intensity sweeteners. Eagan Press, St Paul, Minnesota, USA, p 17-29

14. Wiet SG, Beyts PK (1992) Sensory characteristics of sucralose and other high intensity sweeteners. J Food Sci, 57, 1014-1019

15. Verdi RJ, Hood LL (1993) Advantages of alternative sweetener blends. Food Technol, 47, 94-102

16. Schiffman SS, Sattely-Miller EA, Graham BG, Zervakis J, Butchko HH, Stargel WW (2003) Effect of repeated presentation on sweetness intensity of binary and ternary mixtures of sweeteners. Chem Senses, 28, 219-229

17. Barndt RL, Jackson G (1990) Stability of sucralose in baked goods. Food Technol, 44, 62-66

18. Ellis JW (1995) Overview of sweeteners. J Food Sci, 72, 671-675

19. Hood LL, Campbell LA (1990) Developing reduced calorie bakery products with sucralose. Cereal Foods World, 35, 1171-1182

20. Walter GJ, Mitchell ML (1986) Saccharin. In : Alternative sweeteners. ed Nabors LO, Gelardi RC ed, Marcel Dekker, Inc New York, USA, p 15-41

21. Homler BE (1984) Properties and stability of aspartame. Food Technol, 38, 50-55

22. Park CW (2012) Quality characteristics of rice Makgeolli prepared by mashing types and different yeasts. MS Thesis, Kyungpook National University, Korea, p 5-10

23. Park CS, Lee TS (2002) Quality characteristics of Takju prepared by wheat flour Nuruks. Korean J Food Sci Technol, 34, 296-302

24. Park CW, Jang SY, Park EJ, Yeo SH, Jeong YJ (2012) Quality characteristics of rice Makgeolli prepared by mashing types. Korean J Food Sci Technol, 44, 207-215

25. Park JH, Yeo SH, Choi JH, Jeong ST, Choi HS (2012) Production of Makgeolli using rice treated with Gaeryang-Nuruk Korean J Food Preserv, 19, 144-152

26. So MH, Lee YS, Noh WS (1999) Changes in microorganisms and main components during Takju brewing by a modified Nuruk, Korean J Food Nutr, 12, 226-232

27. Park SK (2013) Characteristics of Makgeolli added with pomegranate. MS Thesis, Kyungnam University, Korea.

28. Song JC, Park HJ (2003) Takju brewing using the uncooked germed brown rice at second stage mash. Korean J Food Sci Technol, 32, 847-854

29. Park JH, Bae SM, Cheol Yook, Kim JS (2004) Fermentation characteristics of Takju prepared with old rice. Korean J Food Sci Technol, 36, 609-615

30. Keen OS, Linden KG (2013) Re-engineering an artificial sweetener : transforming sucralose residuals in water by advanced oxidation. Environ Sci Technol, 47, 6799-6805

31. Kim CJ, Kim KC, Kim DY, Oh MT, Lee SO, Chung ST, Chung JH (1990) Fermentation Technology. Sunjinmunwhasa, Seoul, Korea, p 79-103 